\title{
Assessment of technical condition of historic Penny Bridge in Opole in the context of its restoration
}

\author{
Przemystaw Jakiel $^{1 *}$, and Dariusz Bajno ${ }^{2}$ \\ ${ }^{1}$ Dept. of Roads and Bridges, Faculty of Civil Engineering and Architecture, Opole University of \\ Technology, ul. Katowicka 48, 45-061 Opole, Poland \\ ${ }^{2}$ Dept. of Structural Engineering, Faculty of Civil and Environmental Engineering and Architecture, \\ University of Science and Technology, Al. prof. S.Kaliskiego 7, 85-796 Bydgoszcz, Poland
}

\begin{abstract}
Penny Bridge constructed at the beginning of the 20th century is an important element of Opole city landscape. This footbridge located within Mozart Street upon Młynówka canal is of a particularly decorative character and displays a series of interesting ornaments made both of steel and stone. Its truss girders have a non-typical structure, where bottom chords are horizontal and the upper ones curved and suspended to an additional parabolic tension member (chord). The footbridge, excluding the deck, has remained almost unchanged until the present day, serving the inhabitants of the city for over 100 years. The last renovation of the structure was performed nearly 25 years ago and its steel structure has suffered certain degradation, mainly as far as the layers of paint and losses due to corrosion. In connection with the aforementioned, the footbridge should undergo urgent restoration. Characteristics of the bridge along with its historical background, concentrating mainly on the results of inspections of the structure in the context of assessing its technical condition, has been presented in the paper. Also, selected results of the analysis of bearing capacity of the girder and the proposed scope of restoration work including the requirements of conservation were given.
\end{abstract}

\section{Introduction}

The footbridge located within Mozart Street upon the innavigable Młynówka (Mühlgraben) canal, frequently referred to as Green Bridge and prior to WWII - Penny Bridge, is one of the most valuable bridge monuments in Opole (Fig. 1). Due to its particularly decorative structure and a series of stylish and architecturally pleasing ornaments that prove high skills and craftsmanship of the designer and the contractor, the footbridge is a jewel of the city architecture. The only other structure of similar character is Tumski Bridge in Wrocław built in the 1880s. They are both exceptionally unique truss structures that can be rarely encountered these days with a characteristic upper chord of trusses resembling a parabolic line of the main cable of the suspension bridge, connected in the middle to a pylon supported on the pillar.

\footnotetext{
*Corresponding author: p.jakiel@po.opole.pl
} 
The footbridge was constructed around the year 1900 to provide a convenient connection with the Old Town [1], [2] for the inhabitants of the newly built representative residential area on Pasieka island. Due to the location of the footbridge in the historical part of the city, in direct proximity of sacral monuments and public utility buildings, it has never lost its significance. Green Bridge along with the riverside boulevard and Opole Concert Hall building in the background, is one of the elements most frequently pictured in paintings and photographs and the location of 'Old Opole' most often visited by tourists and inhabitants of the city. The fact that the footbridge remained unchanged despite two World Wars and survived a great flood of 1997 also proves its exceptional character. At present, the structure is associated mainly with numerous padlocks that lovers
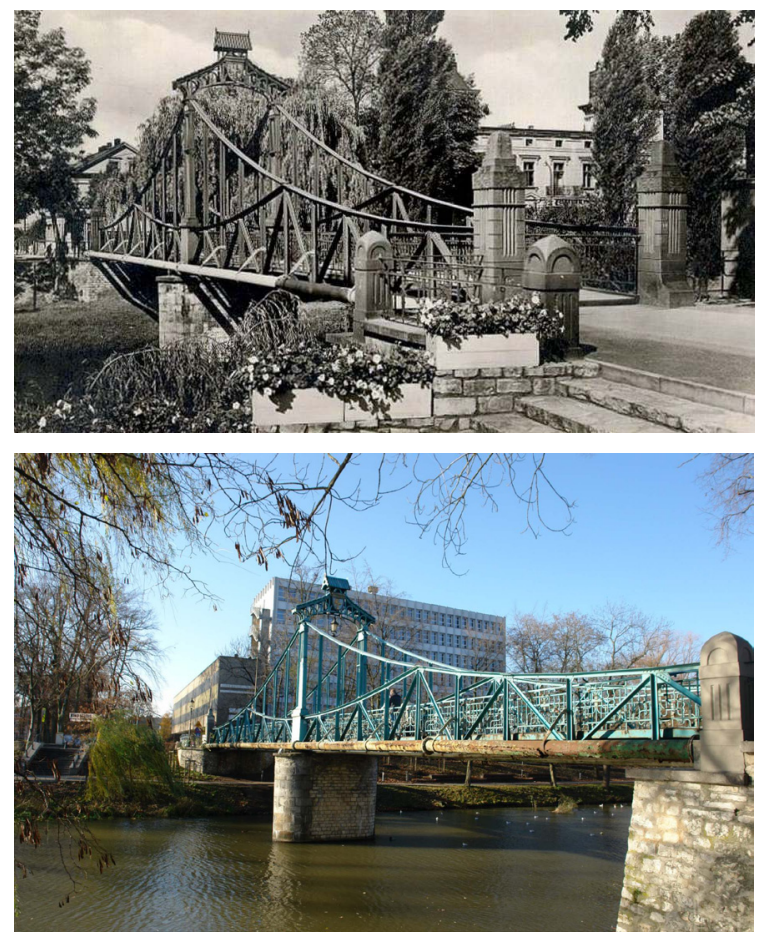

Fig. 1. View of Penny Bridge from Mozart Street in 30s of 20th century [3] (a) and nowadays (b)

have been hanging on its railings following the example of Tumski Bridge mentioned earlier in the text.

At the same time, despite a major renovation of the footbridge performed in the 1990s, over a hundred years of use caused certain damage to steel girders, including degradation of the layers of paint. Therefore, it is necessary to undertake action aiming at restoring the structure to its former glory.

Presentation of the design work performed in connection with the footbridge in order to restore it pursuant to the guidelines of heritage conservation is the aim of this paper. The work consisted in performing a detailed technical inspection of the structure and recording its results, as well as studying the available documents, carrying out checkout calculations of the load-bearing structure capacity and presenting the suggestions for the scope of repair work including in particular the exchange of the anticorrosion layer for a new one [4]. What was taken into account as part of the technical and economic considerations was the fact that the footbridge is a historical structure of an exceptionally unique character integrated into the tissue of Opole as one of its few bridge monuments.

\section{Technical description of the bridge}

The footbridge is composed of two through continuous steel spans with the span length of $2 \times 19.5 \mathrm{~m}$, total length of $39.4 \mathrm{~m}$, usable and total widths of $2.65 \mathrm{~m}$ and $3.4 \mathrm{~m}$ respectively (Fig. 2). In 1992 the bridge was entered in the record of immovable monuments of the Opole Province [2]. The grade of steel which the bridge was made of is not precisely known, however it is assumed that in Germany as early as at the beginning of the 20th century ingot steel was widely produced and steel sheets and rolled sections were made of it. In comparison with forge iron, it was characterised by good tensile strength, 
homogeneity and proper isotropy and its yield strength amounted to $180-240 \mathrm{MPa}$ [5]. This data fully corresponds to the results of expert evaluation of the bridge carried out in 1978 whose findings claimed that the steel which the bridge was made of corresponded to St0S steel with yield strength not lower than $186 \mathrm{MPa}$ [6].

\subsection{Load-bearing structure}

Two continuous double-span riveted spans in the form of trusses with axial spacing of 3.2 $\mathrm{m}$ constitute the load-bearing structure of the bridge. The trusses are of varied height, their diagonals are arranged in the $\mathrm{W}$ shape with additional hangers and posts. Bottom truss chords are straight but the upper ones are curved, pointed in the middle joints of both spans being their highest point. Each truss is suspended in the pillar zone to a segmental parabolic chord (a kind of stiff tension member) symmetrical to the pillar axis, connected (with the use of a hidden joint) to the aforementioned highest truss joint of a given span, as well as to the top of the pylon located on the pillar (Fig 3). Moreover, the structure strengthening the truss girder is composed of hangers connected with the truss in its upper chord joints. The upper and bottom truss chords were made of 2L 100x100x12 mm angle bars. In four middle sections of each span, the upper chord was strengthened with a $24 \times 10 \mathrm{~mm}$ cover plate. Three middle hangers and posts were made of $2 \mathrm{~L} 70 \times 70 \times 9 \mathrm{~mm}$ angle bars, the next two of 2L $75 \times 75 \times 10 \mathrm{~mm}$ ones, the further one of $2 \mathrm{~L} 80 \times 80 \times 10 \mathrm{~mm}$ angle bar, and the first at the side of the abutment was made of 2L 100x100x12 mm angle bar. All diagonals, except the edge ones, were made of 2L 70x70x9 mm angle bars, whereas the first one at the side of the

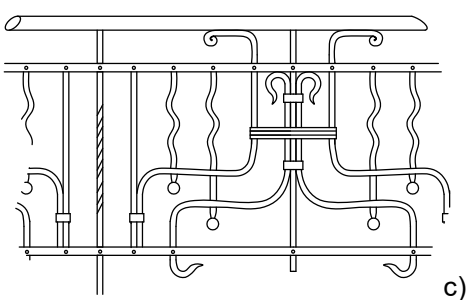

c)

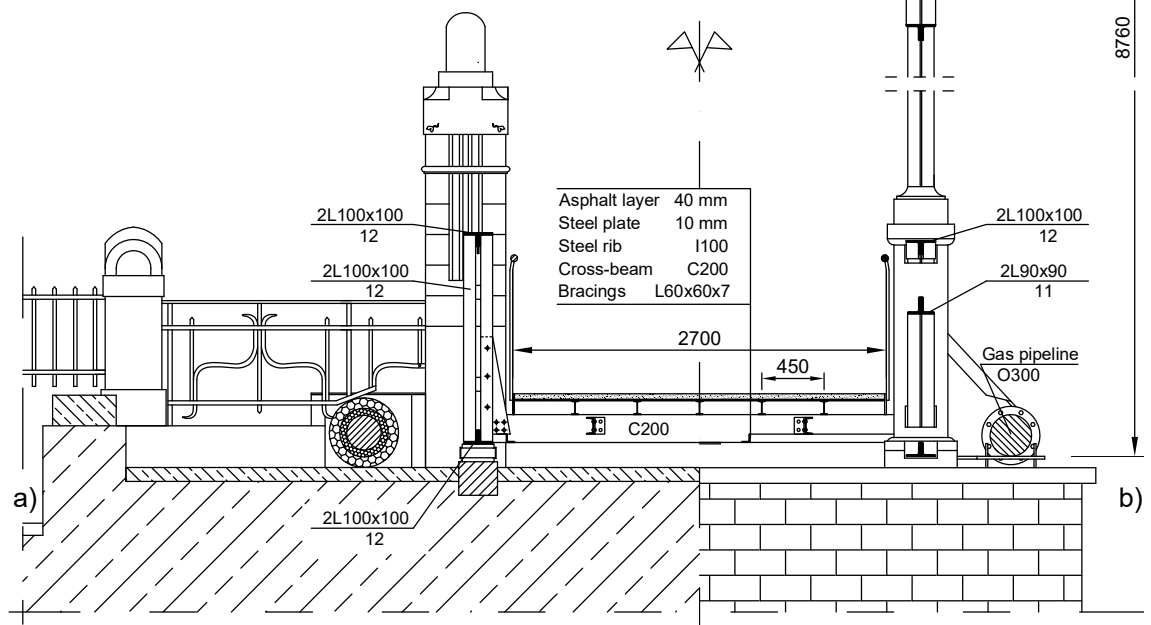

Fig 2. Cross section of the footbridge: a) at the abutment, b) at the pier and c) the railing detail 
abutment was made of $2 \mathrm{~L} 100 \times 100 \times 12 \mathrm{~mm}$ and the edge one next to the pillar of $2 \mathrm{~L}$ 90x90x11 mm profiles. The girders are supported on the piers with the use of steel pinned bearings, fixed (on the pillar) and rolled on the abutments [4], [6].

The pylon fixed in the pillar shaft is an ornamental portal frame with I-section posts $(4 \mathrm{~L}$ $90 \times 90 \times 10 \mathrm{~mm}$ and $800 \times 10 \mathrm{~mm}$ steel plate). Its total height amounts to $8.76 \mathrm{~m}$ and the horizontal clearance of posts at the height of railings is $2.72 \mathrm{~m}$. The bottom part is covered with steel plates to create a plinth. Spandrel beam of the frame was made as an openwork grid covered with a double roof, to which a lamp was attached in the middle along with the crest of Opole (Fig. 2).

\subsection{Deck}

The deck was changed to an orthotropic plate in the early 1990s and is now a modernised version of the original one. Steel plate of the deck, which is $2700 \mathrm{~mm}$ wide and $10 \mathrm{~mm}$ thick, was stiffened with five longitudinal ribs in the shape of I100 I-sections spaced every $0.45 \mathrm{~m}$ (Fig. 2). The entire structure is based on the original U200 cross-beams which are connected with bottom truss joints every $1.95 \mathrm{~m}$. The steel plate deck was limited in the cross section with the use of steel plate overhangs constituting a bed for the pavement and a mounting for balusters. The elements subject to modernisation were made of St3M steel [7].

Two types of cross-beams were used differing from each other in terms of length that is edge cross-beams $(3.17 \mathrm{~m})$ and span ones $(3.36 \mathrm{~m})$, which is due to the necessity to obtain a required longitudinal slope of the deck. All cross-beams are mounted to the girders with the use of $\varnothing 22 \mathrm{~mm}$ rivets. The cross-beams are connected with two U120 stringers spaced every $0.78 \mathrm{~m}$ and also being original bridge elements. The aforementioned modernisation of the footbridge excluded the stringers as elements performing load bearing function but they were retained due to their historic assets.

In the plane of the bottom truss chords there are the $\mathrm{X}$ type bottom horizontal bracing made of $\mathrm{L} 60 \times 60 \times 10 \mathrm{~mm}$ angle bars at the length of two truss modules.

\subsection{Fittings}

Pavement of the footbridge was made of $40 \mathrm{~mm}$-thick asphalt layer on top of steel plate with the average longitudinal slope of $0.5 \%$ towards Piastowska Street. The pavement on the crown of the abutment on the side of Piastowska Street is made of granite paving stones, whereas on the opposite end it is made of concrete paving stones.

Original steel Art Nouveau parapet was made of forged poles with square, rectangular or channel shape cross-sections and spherical elements were added. Handrails in the span area were made of tubular profiles $(\mathrm{d}=50 \mathrm{~mm})$ at the height of $1.0 \mathrm{~m}$. Apart from the span area, the railings are also located on the abutments at the access to the structure. Additionally, the very entrance to the footbridge is emphasised by stone plinths decorated with Art Nouveau ornaments and connected with the parapet.

The deck is drained by way of gravitation and also with the use of deck drainers located in the deck plate. Spans were connected on the abutments by means of steel plate expansion joints in the gaps in which there are residues of extension putty. At each entrance to the footbridge there is a pair of ornamental lamps made of cast iron and steel. In addition, there is a single lamp attached below the spandrel beam of the pylon, identical to the ones located at the entrances to the footbridge, and of the spandrel beam itself there is the crest of Opole mounted on both sides.

Numerous utilities have been run through the footbridge, that is $\varnothing 300$ and $\varnothing 400 \mathrm{~mm}$ 


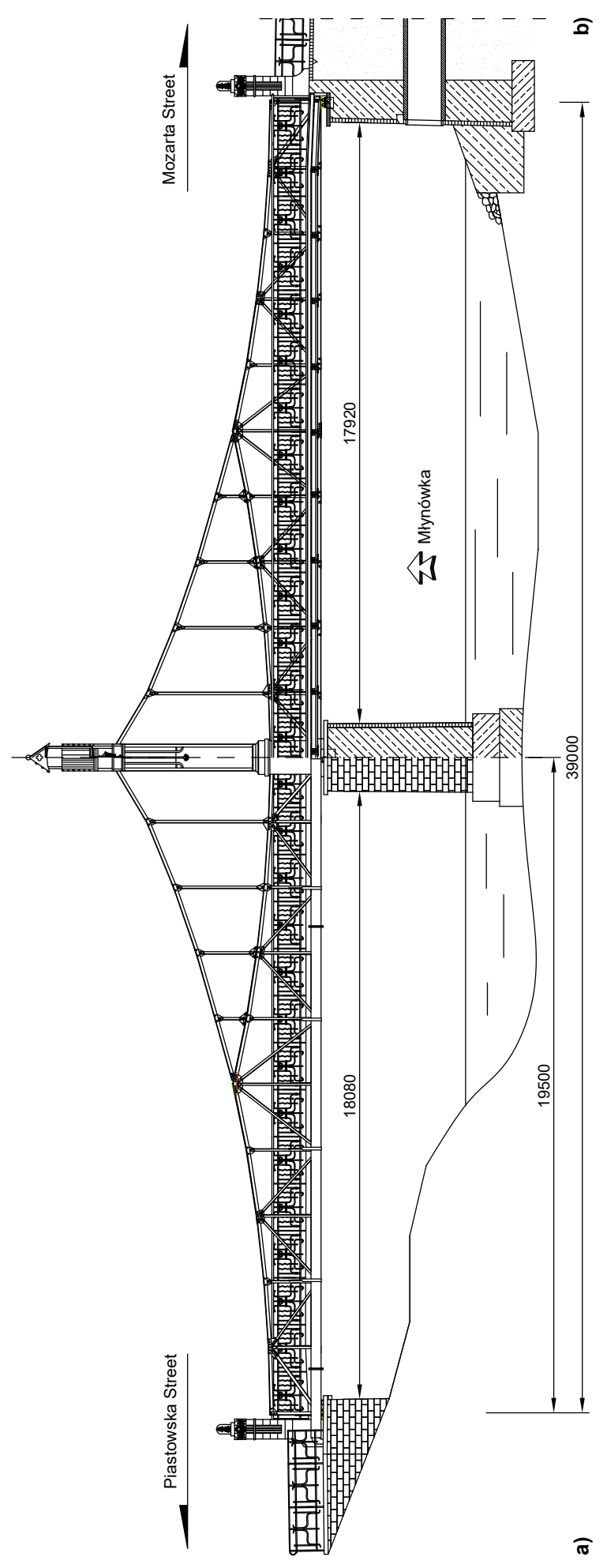

pipelines suspended to the girders, from the upper and bottom side of the water respectively, as well as telecommunications and energy carriers placed in nine steel pipes with the diameters of $100 \mathrm{~mm}$ and $90 \mathrm{~mm}$ (Fig. 2 and 3 ).

\subsection{Piers}

All piers are made of stones connected with the use of cement mortar and the bearing slabs are made of granite. The right bank abutment faced with the retaining wall of the river bank is $5.5 \mathrm{~m}$ high counting from the offset of the foundation. In the headwall under the span there is an outlet of the storm interceptor of the urban sewage system with the diameter of $0,6 \mathrm{~m}$ covered with a steel hatch. The abutment on the side of Piastowska Street is additionally composed of diagonal wings.

In case of the pillar, in order to protect it against floating ice the front part of its shaft was faced with granite blocks. In plane view, it is of oval shape with footprint diameters amounting to $2.1 \times 4.7 \mathrm{~m}$, with the shaft height of 4.5 $\mathrm{m}$, counting from the offset of the foundation to the axis of the bearings. Pillar foundation as recorded in 1964 has approximate dimensions of $5.9 \times 2.9 \times 2.0 \mathrm{~m}$ and is mounted at the depth of about $3.7 \mathrm{~m}$ below water level. All piers are directly founded [8]. 


\section{Assessment of technical condition}

Technical inspection of the footbridge encompassed the load-bearing structure of the spans along with the deck, piers and fittings [4]. The assumed assessment scale ranged from 0 (failure condition) to 5 (proper condition) in accordance with [9]. Assessment grades assigned to individual footbridge elements under scrutiny are presented in Figure 4. On the basis of the existing documentation of the structure it was found that in the period 1945 1992, the footbridge underwent a few minor repairs, whereas in 1993 its major renovation was performed consisting in, among others, modernisation of the deck and renovation of the piers $[6,7]$.

\subsection{Load-bearing structure and deck}

Discolouration and losses in the layer of paint were found on a significant area of the truss girders, which is connected with intense UV radiation. The biggest corrosion spots are present on the bottom truss chords in proximity of the joint steel plate and other not easily accessible parts of the structure. Contact points of the upper chords and overlays are also significantly degraded due to corrosion and swelling occurred that deformed the connected elements by as much as $20 \mathrm{~mm}$ (Fig. 5a). In the support zones of the bottom chords there are soil residues and dry leaves and on the upper chords of the girders biological corrosion in the form of moss can be locally observed. The above mentioned damage poses no direct threat to the safety of the footbridge but it is of influence on further degradation of the structure and it deteriorates its aesthetic appearance.

There are local losses in the layer of paint on the pylon, as well as contamination and deep corrosion of steel plates covering the posts (Fig. 5b), which facilitates penetration by rain water leading to continuous degradation of the structure.

On the bottom surface of the deck (steel plate, longitudinal ribs, cross-beams and stringers, horizontal bracing) paint flaking was observed, as well as local corrosion spots. Significant corrosion was also noted in the selected joints of cross beams and girders.

\subsection{Fittings}

Minor surface losses of asphalt were the only shortcoming found in the footbridge pavement, however after rainfall, damp tends to be retained near the edges which is due to improperly shaped footbridge structure slopes. In case of pavement at the access to the footbridge, only slight concrete pavement subsidence was observed on the right river bank abutment.

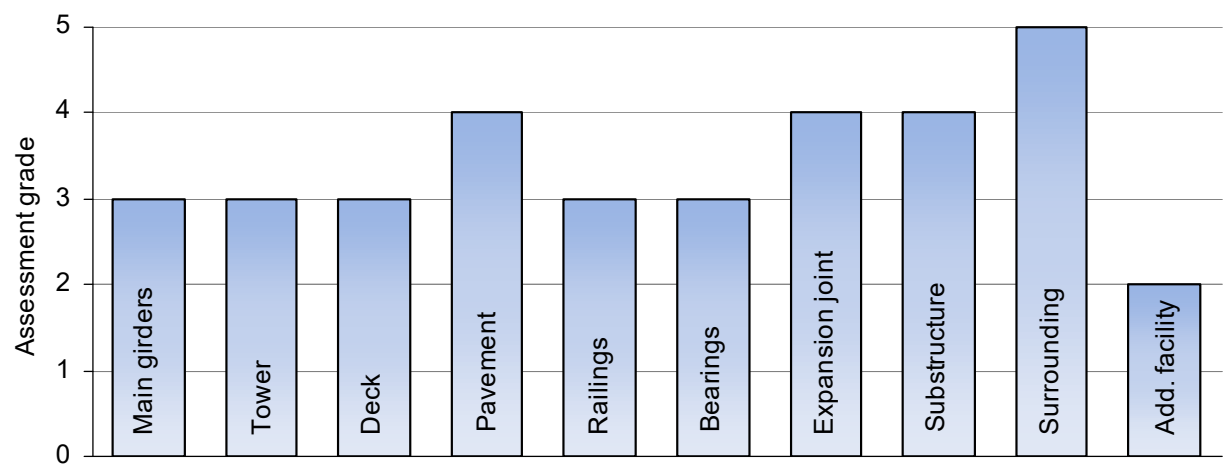

Fig. 4. Assessment of technical condition of the footbridge elements [4] 

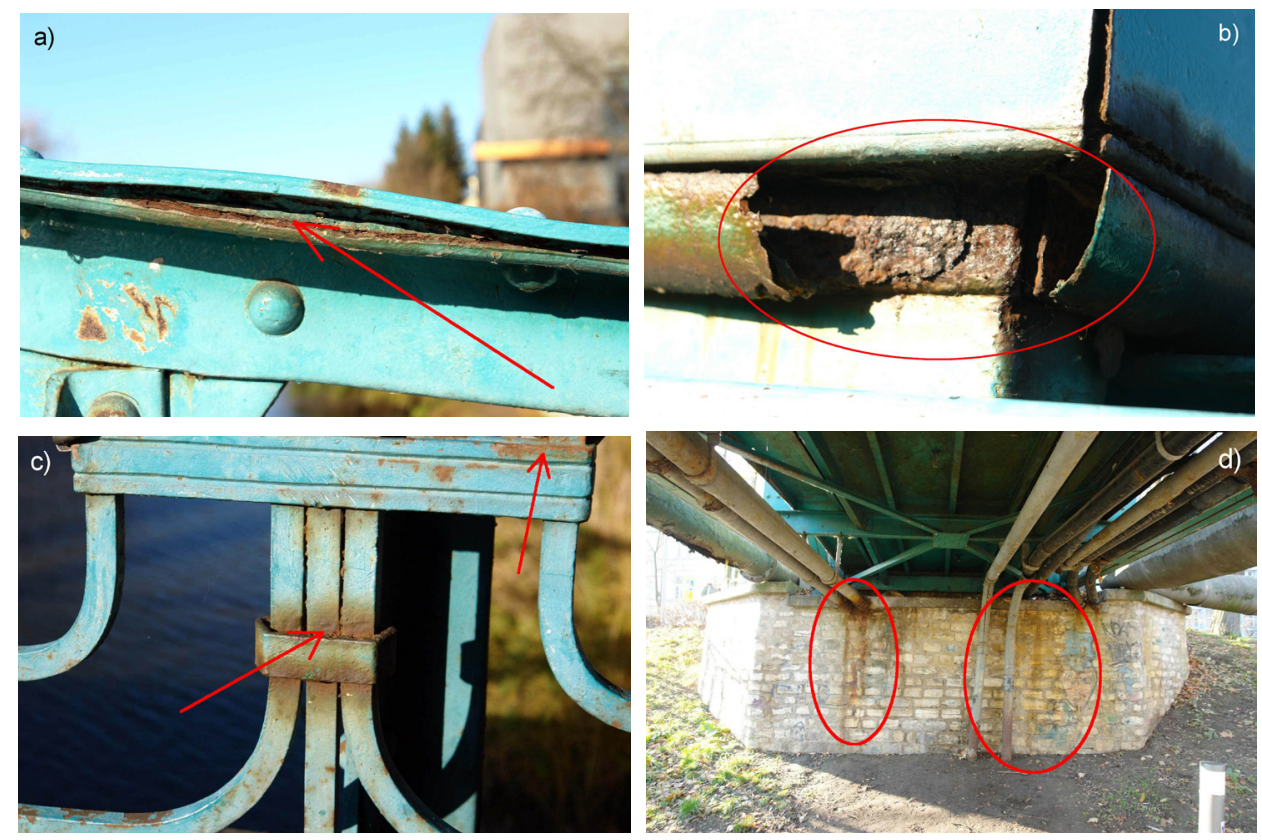

Fig. 5. Recorded damage of the structure: a) corrosion of the girder, b) pitting corrosion of the pylon, c) surface corrosion of the parapets, d) rusty stains on the left-bank abutment, corrosion of the casings of utilities

Local contamination, losses in layers of paint and surface corrosion spots (Fig. 5c) can be seen on the surface of parapets. Railings at the entrance to the footbridge from Piastowska Street are deformed and numerous padlocks, which facilitate damp absorption and retention and initiate corroding processes, have been fixed to the span parapets. It should be added at this point that the brick plinths located at the entrances to the structure have been restored in recent years [10].

All bearings on the footbridge are highly contaminated and locally corroded which is of adverse effect on the work of these elements and main girders.

There were also lacks of the filler of expansion joints noted, as well as dirt retained in the cracks that were formed as a result.

\subsection{Piers}

Condition of abutments does not give rise to any objections and it was only in the parapet base of the right-bank abutment wing that scratches and local mortar debondings were observed. On the shafts of both piers, intense rusty water stains can be seen that come from steel casing pipes of utilities that are subject to corrosion (Fig. $5 \mathrm{~d}$ ). On the bearing slab of the left-bank abutment a growing bush was found that adversely affects the structure of the pier and span.

Condition of the pillar shaft does not give rise to any objections, excluding minor stains made by calcium carbonate washed off from the mortar joining the stones. Both the pillar and the left-bank abutment are covered with graffiti.

All piers were subject to repair work in the 1990s [8]. 


\subsection{Surroundings of the structure and utilities}

Riverbank slopes in the direct surroundings of the footbridge are in proper condition and bushes have been removed from the bank line nearby.

Pipeline suspended to the spans from the south side is deeply corroded, whereas pipeline casing from the north side is covered with moss efflorescence. The casing is locally deformed and damaged at the right-bank abutment. Condition of both metal and plastic pipe casings under the deck is insufficient. They are deeply corroded on the side overlooking Piastowska Street and the rainwater that flows down these pipes damages the left-bank abutment. The presented condition of utilities is of adverse influence mainly on the aesthetic appearance of the footbridge.

\section{Analysis of the load-bearing capacity of the footbridge}

On the basis of the recorded measurements of the structure, analysis of the current loadbearing capacity of the main girders has been performed by means of applying dead and life loads pursuant to the PN-EN 1991-2 standard (Actions on structures. Traffic loads on bridges). Checking the load applied by emergency vehicles was omitted in these calculations as it is impossible for such vehicles to enter the footbridge. In order to determine extreme values of axial forces in truss bars, influence lines were applied. As a result of calculations, values of normal stresses were obtained in all truss bars and it was verified that the edge and internal half-frames met the strength conditions. The highest stresses in tension occur at the diagonal No. 50, near the pylon, $\sigma_{50}=79.8 \mathrm{MPa}$, and the highest stresses in compression can be observed in the first rod of the middle chord No. 21 , $\left|\sigma_{50}\right|=80.6 \mathrm{MPa}$. The obtained stresses were referred to the computational tensile strength of S185 steel (equivalent of St0S steel), that is $\mathrm{R}=153.2 \mathrm{MPa}$. Selected results of the Ultimate Limit State (ULS) calculations were presented in Figure 6. Following the analysis of span deflection, it was found that the maximum value amounts to $32 \mathrm{~mm}$ and is smaller than the permissible value of $51 \mathrm{~mm}$.

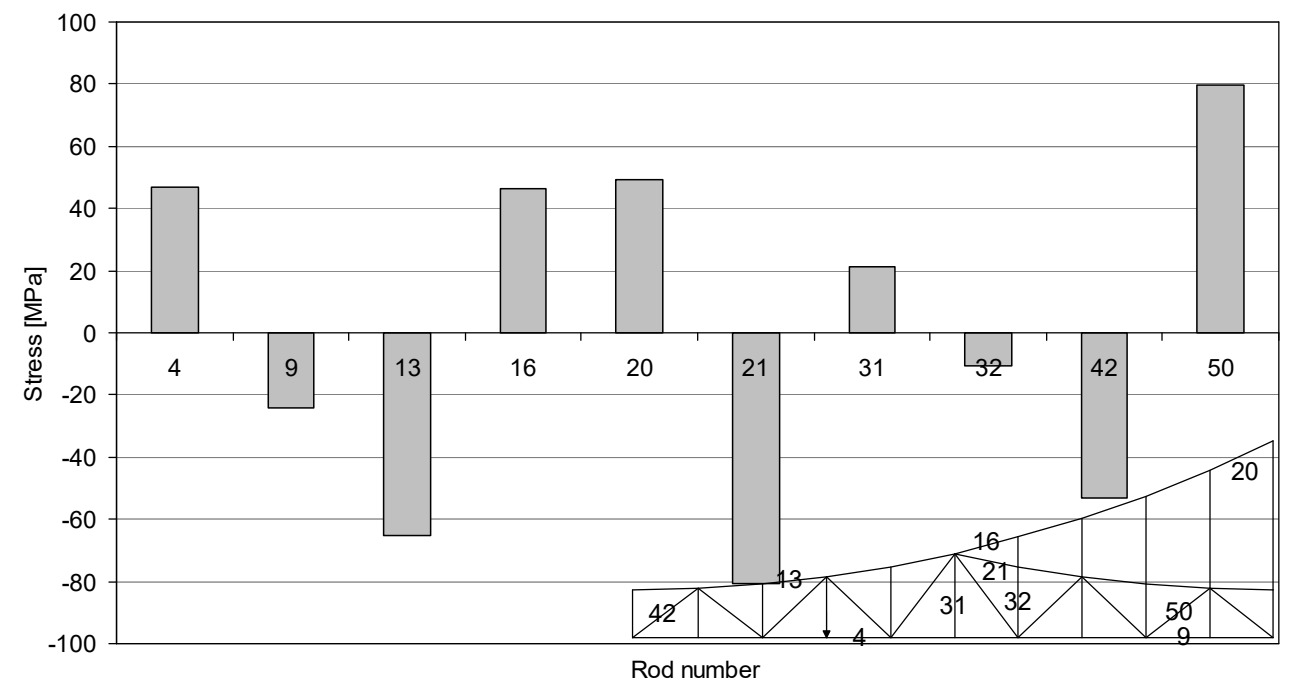

Fig. 6. Diagram of extreme normal stresses in chosen girder's bars 


\section{Scope of forecasted renovation work}

On the basis of the carried out technical inspection of the structure and the damage found, it was recommended to carry out the following repair work as soon as possible:

- exchanging the corroded steel plates covering the posts of the pylon for new ones,

- carrying out new anticorrosion protection of the entire steel structure,

- removing padlocks from the railings,

- removing dirt from the bridge bearing cavities,

- cleaning and maintaining the bearings,

- carrying out maintenance work of the utilities, preferably aiming at removing them should they fail to perform their initially assumed function,

- cleaning the expansion joints and filling gaps,

- removing stains from the piers,

- repairing the damaged pavement surface at the entrance to the footbridge from Mozart Street.

Particular attention was drawn to the manner of renovating the layers of paint on the footbridge, which was the subject of consultations carried out with the Province Monument Conservator in Opole. Their renovation is aimed at exposing aesthetic and architectural assets of the structure, whereas work must be done in a manner not posing threat to the original structure and fittings. Morever, it was assumed that:

- anticorrosion protection shall encompass the following elements: main girders, pylon, deck plate with the grid, bearings and parapets,

- new anticorrosion protection of the structure shall be based on classic layers of paint, without metallization (the colour of the structure and parapets shall change in comparison to the existing colours - Figure 7),

- renovation work shall be performed on the structure as it is (no necessity to disassemble the structure)

- removing rust and old layers of paint from the structure, as well as application of the new ones shall be carried out in an environmentally friendly manner,

- after the structure has been cleaned, but prior to the application of new layers of paint, assessment of the level of damage of the steel elements should be performed again and a decision should be made concerning the possible exchange of chosen elements for new ones,

- it is required that the entire work on the structure is supervised by the monument conservator,

- repair work shall be carried out while the footbridge is closed for pedestrian traffic.
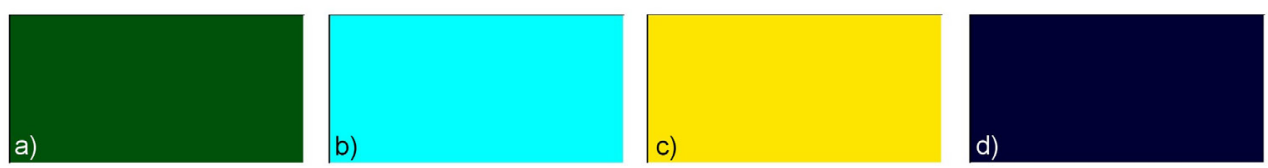

Fig. 7. New colour scheme of the footbridge: a) load-bearing structure and parapets, b) c) the crest of Opole on the pylon, d) the lamp on the pylon

\section{Conclusion}

The fact that the monumental steel Green Bridge in Opole has been used for over a hundred years proves its unquestionable durability. Nevertheless, despite maintenance work 
occasionally performed by various administrators of the footbridge, as well as modernisation of the deck, the recently carried out its technical inspection provides grounds to assume that at present the utilities are in the poorest condition. On the other hand, technical condition of steel elements of the structure is comparable to this of fittings, at a relatively low level, which is influenced by similar degradation of the layer of paint and corrosion intensity, particularly in the areas hidden from the sun. Due to the aforementioned, it was suggested to perform a complex anticorrosion protection of the load-bearing structure of the footbridge and the parapets by applying new colour schemes to these elements. These activities should be preceded by the removal of other indicated damage, as well as by carrying out an additional verification of the structure after the existing layer of paint has been removed. At the same time, the analysis of the load-bearing capacity of the girders showed that it was ensured and thus there is no necessity to stiffen them any further.

To summarise, the footbridge is a unique and valuable example of a historic bridge structure being the showcase of Opole and therefore it should be treated with particular care consisting in carrying out periodic renovation and maintenance work, necessarily supervised by the monument conservator, in order to maintain the original form and material of this beautiful structure.

\section{References}

1. A. Hamada, Architektura Opola wpisana w dzieje miasta (Architecture of Opole inscribed in the history of the city). Wyd. Oficyna Piastowska, Opole 2008 (in Polish)

2. Pedestrian bridge over Młynówka canal in Opole. Green Bridge. Record sheet of the monuments of architecture and construction. Monument Documentation Centre in Warsaw, 1993

3. http://fotopolska.eu/foto/39/39575.jpg

4. Conservation procedure design with respect to renovation of the layers of paint on the historical footbridge over Młynówka canal within Mozart Street in Opole. Biuro Projektów i Ekspertyz BiS PROJEKT, Opole 2016 (in Polish)

5. K. Czapliński, Old-time products made of ferrrous alloys. Dolnośląskie Wydawnictwo Edukacyjne, Wrocław 2009 (in Polish)

6. Technical expertise No. 29/77/78 concerning technical condition and further serviceability of the footbridge over Młynówka canal within 24 March Street in Opole. PZITB, Wrocław 1978 (in Polish)

7. Technical design of repair work and modernisation of the footbridge deck over Młynówka canal within Mozart Street in Opole pursuant to version III of the conceptual design. Mostar, sp. z o.o., Wrocław 1992 (in Polish)

8. Development of technical design for repair work and modernisation of the abutments and pillar of the footbridge over Młynówka canal within Mozart Street in Opole. Mostar, sp. z o.o., Wrocław 1993 (in Polish)

9. Instructions for carrying out inspections of road engineering structures. General Director for National Roads and Motorways, Warsaw 2005 (in Polish)

10.Documentation of conservation work on pylons and towers with decorative domes at the historical Penny Bridge over Młynówka canal in Opole. Art Gallery „Autor”, Opole, 2010 (in Polish) 